\title{
Vertailevan kasvatustieteen perusteos
}

Suvi Jokila, Johanna Kallo \& Risto Rinne (toim.) (2015).

Comparing times and spaces. Historical, theoretical and methodological approaches

to comparative education. SKTS. 258 s. ISBN 978-952-5401-71-4

VERTAILEVAN KASVATUSTIETEEN ALKUVAIHE sijoitetaan jopa 1800-luvun lopulle. Vaikka yli sata vuotta sitten tehty tutkimus ei juurikaan muistuta teorialähtökohdiltaan ja menetelmiltään tämän päivän vertailevaa tutkimusta, yhteisiä kehyksiä on kuitenkin tunnistettavissa.

Vertailevassa tutkimuksessa on ollut aina kysymys tietynlaisesta uteliaisuudesta kotoisen ulkopuolella olevaa kohtaan. Yli sata vuotta sitten ulkopuolella oleva muodostui nykyistä suppeammista kiinnostuksenkohteista. Toisaalta koko vertailevan kasvatustieteen historian ajan tutkimustuloksilla näyttää olleen merkittävää käyttöarvoa kasvatusta ja koulutusta eri tavoin uudistettaessa ja kehitettäessä.

2000-luvulla vertailevan kasvatustieteen haasteeksi on noussut monin tavoin muuttuva maailma. Globalisaation nopeus ja laajuus sekä ylikansallisten organisaatioiden vaikutusvalta ovat haastaneet tutkijoita tarkastelemaan vertailun kenttiä uusista näkökulmista. Kansallisvaltioiden rooli vertailun perusyksikkönä on merkittävästi aiempaa pienempi. Edelleen on nähtävissä ajassa vertikaalisen vertailun kasvavan horisontaalisen rinnalla. Muutokseen ja siirtymiin kohdistuva tutkimus on luonut pohjaa vertailevan tutkimuksen teoreettiselle ja metodologiselle laajenemiselle.

\section{VERTAILEVA TUTKIMUS VAHVISTUU}

Vertaileva kasvatustieteellinen tutkimus näyttää viime vuosina vankistaneen asemaansa niin Suomessa kuin kansainvälisestikin. Tutkijoiden määrä on selvästi nousussa ja tutkimustuloksista ollaan aiempaa kiinnostuneempia myös tutkijayhteisön ulkopuolella.

Tutkimuksen uusista haasteista ja niihin vastaamisen keinoista kertovat tekstit eivät ole 
välttämättä pysyneet muuttuvien tutkimustarpeiden kyydissä. Jo tästäkin näkökulmasta on nähtävä myönteisenä tuotoksena tässä arvioitava julkaisu.

Teoksen tekstit on jaettu kolmen pääteeman alle. Vertailevan tutkimuksen historiallisia aspekteja Pohjoismaissa käsittelee kaksi artikkelia. Vertailevan tutkimuksen teoreettisiin ulottuvuuksiin paneudutaan kolmessa artikkelissa. Kolmas teema-alue on edellisiä huomattavasti laajempi. Eurooppalaista ja Euroopan ulkopuolista koulutuksen ja koulutuspolitiikan tilaa käsitellään varsin erilaisista lähtökohdista seitsemässä artikkelissa.

Nyt arvioitava teos perustuu vuonna 2013 pidetyn konferenssin esityksiin. Siitä, missä määrin kirjan artikkeleiksi on valikoitunut konferenssin kiinnostavimmat ja tasokkaimmat artikkelit, ei ole tarkempaa tietoa. Joka tapauksessa kirjassa näkyy tyypillisiä konferenssikoosteiden piirteitä. Teemojen koossapito on ollut paikoin hankalaa ja yksittäisten artikkeleiden taso vaihtelee todella tasokkaista varsin tavanomaisiin.

\section{HAJANAINEN ALOITUS}

Kirjan ensimmäisen teema-alueen artikkelit, O’Dowdin, Winter-Jensenin ja Wikanderin pohjoismaisen vertailevan kasvatustieteen historian tarkastelu sekä Lawnin kahden vertailevan tutkimuksen uranuurtajan - Laurin Zilliacus ja Torsten Husen - ajatusten ja tuotosten esittely ja arviointi, eivät ole kirjan vahvinta antia.
Ensiksi mainittu artikkeli jää hajanaiseksi ja siinä näkyy selvästi lievä perehtymättömyys koko Pohjoismaiden alueen vertailevan kasvatustieteen kehitykseen ja tuloksiin. Näyttää kuin kirjoittajat olisivat jättäneet aineiston haun kesken. Toinen artikkeli on henkilöhistorian näkökulmasta toki kiinnostava ja sellaisena antoisa. Torsten Husenin merkitys kasvatustieteelle yleensä on todettu lukuisissa teksteissä ja yhteyksissä.

Suomalaisen koulun PISAmenestyksen tulkitsijana erityisesti Yhdysvalloissa tunnettu Pasi Sahlberg tarkastelee artikkelissaan globaalin koulutusreformiliikkeen (GERM) nousua ja tulkintoja. Jäsennelty artikkeli tarjoaa selkeän kuvan koulutusreformin luonteesta. Toisaalta vahvasti amerikkalaisesta näkökulmasta tulkittu ilmiöiden globaalisuus jättää monien väitteiden argumentit puolinaisiksi.

Taina Saarinen tarkastelee monipuolisesti korkeakoulupolitiikan tutkimusta ja käsityksiä korkeakoulupolitiikan ylikansallisista ulottuvuuksista. Artikkeli tarjoaa laajan näkökulman korkeakoulupolitiikan ilmiöihin ja niiden tutkimiseen eilen, tänään ja tulevaisuudessa. Saarinen on tarttunut ansiokkaasti suomalaisen korkeakoulupolitiikan ja korkeakoulutuksen kehyksessä kysymykseen vieraista kielistä ja kansainvälistymisestä. Hän kritisoi kansainvälistymisen ja englannin kielen samaistamisesta. Huomio on myös vertailevan kasvatustieteellisen tutkimuksen näkökulmasta varteenotettava. Onkin hieman para- doksaalista havaita nyt arvioitavan teoksen artikkeleiden lähdemateriaalinen kielellinen yksipuolisuus.

\section{KANSAINVÄLISTYMISEN HAASTEITA}

Rosario Maniscalcon koulutuspolitiikan eurooppaistumista tarkastelevan monipuolisen tekstin teräviin havaintoihin kuuluu muistutus koulukseen kytketystä subsidiariteettiperiaatteesta, kansallisesta itsemääräämisoikeudesta. Maniscalco tuo esiin lukuisin faktoin sen, millaisin keinon Euroopan Unionin koulutuspoliittiset linjaukset on saatu osaksi kansallista koulutuspolitiikkaa ilman näkyvää subsidiariteettiin puuttumista.

Korkeakoulutuksen kansainvälistymisen ja rakenteellisen yhdenmukaistumisen taustat ja luonne ovat laajempi teema Elisabeth Agbor Etan artikkelissa, joka perustuu kirjoittajansa tohtorityössään käsittelemään Bologna prosessin soveltamista Kamerunissa. Alkuperäisesti eurooppalaisen harmonisaatiohankkeen soveltamista afrikkalaiseen korkeakoulutukseen voi pitää yllättävänäkin ajatuksena. Toisaalta muistaen afrikkalaisen siirtomaahistorian ja sen aikana rakennetut korkeakoulujärjestelmät, ei ajatus tunnukaan niin mahdottomalta. Eta tunnistaa artikkelissaan tämän ja myös yleisemmän korkeakoulutuksen kansainvälistymisen mukaan tuoman yhtenäistämishaasteen.

Eurooppalaisen korkeakoulutuksen haasteet ja linjanvedot nousevat osin samoista globaa- 
leista vaatimuksista kuin muissakin maissa. Kyseisiä haasteita käsittelevässä Rabinowiczin ja Chinapin artikkelissa tuodaan näkyviin monia jo ennestään tuttuja trendejä, joilla on vahva eurooppalaista korkeakoulutusta muovaava vaikutus. Tässä yhteydessä ei ole syytä unohtaa myös kirjoittajien korostamaa koulutuspolitiikan ja korkeakoulutuksen entistä tiiviimpää sidosta talouspolitiikkaan ja koulutuksen kilpailukyvyn välineeksi alistamista.

Suvi Jokilan suomalaisten yliopistojen kansainvälistymistä kä- sittelevän artikkelin taustana olevan tutkimuksen aineisto koostuu opetusministeriön kolmen tason asiakirjoista: kansainväliset strategiat, yleissuunnitelmat ja aluekohtaiset strategiat. Aineistonsa analyysin perusteella Jokila tekee johtopäätöksen kansainvälistymisen rakentumisesta enemmän alueellisessa kuin globaalissa kehyksessä

Jokilan, Kallon ja Rinteen laatima yhteenvetoluku on mainio analyysi ja tiivistys kaikista teoksen artikkeleista tarjoten näin lukijalle vielä mahdollisuuden vertailla omia tulkintojaan kirjan toimittajien näkemyksiin.

Nyt arvioitu teos on välttämätön lisä suomenkieliseen vertailevan kasvatustieteen peruskirjastoon. Huolimatta siinä olevien artikkeleiden laadun vaihtelusta kokonaiskuva tieteellisestä ja konkreettisesta annista jää vahvasti positiivisen puolelle.

Eero Pantzar

$K T$, dosentti

Tampereen yliopisto 